\title{
E-NTPDases in human airways: Regulation and relevance for chronic lung diseases
}

\author{
Lauranell H. Burch • Maryse Picher
}

Received: 11 January 2005 / Accepted: 21 December 2005 / Published online: 30 May 2006

(C) Springer Science + Business Media B.V. 2006

\begin{abstract}
Chronic obstructive lung diseases are characterized by the inability to prevent bacterial infection and a gradual loss of lung function caused by recurrent inflammatory responses. In the past decade, numerous studies have demonstrated the importance of nucleotide-mediated bacterial clearance. Their interaction with $\mathrm{P} 2$ receptors on airway epithelia provides a rapid 'on-and-off' signal stimulating mucus secretion, cilia beating activity and surface hydration. On the other hand, abnormally high ATP levels resulting from damaged epithelia and bacterial lysis may cause lung edema and exacerbate inflammatory responses. Airway ATP concentrations are regulated by ecto nucleoside triphosphate diphosphohydrolases (E-NTPDases) which are expressed on the mucosal surface and catalyze the sequential dephosphorylation of nucleoside triphosphates to nucleoside monophosphates (ATP $\rightarrow$ ADP $\rightarrow$ AMP). The common bacterial product, Pseudomonas aeruginosa lipopolysaccharide (LPS), induces an acute reduction in azide-sensitive ENTPDase activities, followed by a sustained increase in activity as well as NTPDase 1 and NTPDase 3 expression. Accordingly, chronic lung diseases, including cystic fibrosis (CF) and primary ciliary dyskinesia,
\end{abstract}

L.H. Burch

Laboratory of Respiratory Biology,

National Institute of Environmental Health Sciences,

Research Triangle Park, Durham, North Carolina, USA

M. Picher (

Cystic Fibrosis/Pulmonary Research and Treatment Center,

School of Medicine,

University of North Carolina,

7010 Thurston-Bowles Building, Chapel Hill, NC 27599, USA

e-mail: pichm@med.unc.edu are characterized by higher rates of nucleotide elimination, azide-sensitive E-NTPDase activities and expression. This review integrates the biphasic regulation of airway E-NTPDases with the function of purine signaling in lung diseases. During acute insults, a transient reduction in E-NTPDase activities may be beneficial to stimulate ATP-mediated bacterial clearance. In chronic lung diseases, elevating E-NTPDase activities may represent an attempt to prevent P2 receptor desensitization and nucleotide-mediated lung damage.

Keywords apyrase - bacterial clearance CD39 . chronic obstructive lung diseases · diphosphohydrolase . endotoxin · purinergic signaling · oxidative stress
Abbreviations
ADP adenosine $5^{\prime}$-diphosphate
AMP adenosine 5'-monophosphate
ATP adenosine $5^{\prime}$-triphosphate
ASL airway surface liquid
MCC mucociliary clearance
CCS cyclic compressive stress
$\mathrm{CF} \quad$ cystic fibrosis
CFTR cystic fibrosis transmembrane regulator
ENAC epithelial sodium channel
IL-1 $\beta$ interleukin-1beta
IL-8 interleukin-8
LPS lipopolysaccharide
MCC mucociliary clearance
NS AP non-specific alkaline phosphatase
PCL periciliary liquid
PCR polymerase chain reaction
$\mathrm{TNF} \alpha$ tumor necrosis factor alpha
UTP uridine 5'-triphosphate 


\section{Introduction}

Airway epithelia constitute an essential protective barrier against lung infection, coordinating luminal and interstitial responses to inhaled pathogens through signals (growth factors, cytokines and nucleotides) provided by epithelial, inflammatory and immune cells [1]. It is now widely accepted that extracellular nucleotides provide an elaborated cell communication system in mammalian tissues [2,3] including the airways [4, 5]. Each signaling event constitutes a brief 'on-and-off' switch mechanism allowing the target cells to perceive the subsequent signal. The major source of extracellular nucleotides in normal airways is the epithelium, releasing ATP under resting conditions and in response to mechanical or osmotic stress [6]. While basal ATP concentrations maintained under resting conditions are insufficient to activate surface receptors, the levels reached near the site of stimulated release initiate a variety of $\mathrm{P} 2$ receptor-mediated responses [7]. Two P2 receptor families have been identified: Fast-acting (ionotropic) P2X ligand-gated cation channels and slow-acting (metabotropic) G protein-coupled P2Y receptors [8]. Although ATP activates members of both families, $\mathrm{P} 2 \mathrm{X}$ receptors generally respond to higher concentrations $\left(\mathrm{EC}_{50}=1-10 \mu \mathrm{M}\right)$ than $\mathrm{P} 2 \mathrm{Y}$ receptors $\left(\mathrm{EC}_{50}=0.1-1.0 \mu \mathrm{M}\right)$. Each signal is promptly terminated by surface conversion of ATP to adenosine $[9,10]$ and dispersal into the interstitial fluid. Adenosine also initiates cellular responses through $\mathrm{P} 1\left(\mathrm{~A}_{1}\right.$, $A_{2 A}, A_{2 B}$ or $A_{3}$ ) surface receptors [11]. In the airways, nucleotide- and adenosine-mediated communications are involved in wound healing [4], bacterial clearance [12] and inflammatory responses [1, 3, 13, 14].

Cell surface nucleotide concentrations are regulated by three families of ectonucleotidases in mammalian tissues: Ecto-nucleotide pyrophosphatase/phosphodiesterases (E-NPPs: ATP $\rightarrow$ AMP), alkaline phosphatases (APs: ATP $\rightarrow$ AMP $\rightarrow$ AMP $\rightarrow$ adenosine) and ecto-nucleoside triphosphate diphosphohydrolases (E-NTPDases: ATP $\rightarrow$ AMP $\rightarrow$ AMP) [15]. This review describes the importance of regulating extracellular nucleotide concentrations for airway homeostasis and the impact of chronic lung diseases on E-NTPDases. Few studies have addressed the activity or expression of airway E-NTPDases. In this review, the available information is complemented by original data.

\section{Nucleotide-mediated bacterial clearance}

The importance of purine signaling in the airways is well illustrated in nucleotide-mediated mucociliary clearance (MCC), which constitutes the first line of defense against bacterial infection [16]. Mucosal epithelial surfaces are protected by an airway surface liquid (ASL) layer containing a thin mucin sheath kept above the cilia by a periciliary liquid (PCL) layer (Fig. 1). Inhaled bacteria adhere to the mucin and are continuously displaced upward by coordinated cilia beating activity $[17,18]$. Comparative analysis of the bioelectric properties of airway epithelia from normal donors and $\mathrm{CF}$ patients revealed that PCL height is regulated by a delicate balance between the activities of the epithelial sodium channel (ENAC) and the cystic fibrosis transmembrane regulator (CFTR) [19]. Cystic fibrosis is characterized by mutations in the gene encoding CFTR [16]. The lack of ion secretion through CFTR is associated with $\mathrm{Na}^{+}$hyperabsorption by ENAC and water influx, resulting in the depletion of the PCL layer essential for cilia beating activity. The cilia become collapsed under a thick layer of mucus filled with bacteria and leukocytes, leading to severe inflammatory responses and progressive loss of lung function.

Extracellular nucleotides and nucleosides regulate CFTR and ENAC [20]. The basal activity of CFTR is maintained by adenosine $\left(\mathrm{A}_{2 \mathrm{~B}}\right)$ receptors, which induce $\mathrm{G}$ protein-coupled adenylate cyclase, followed by cAMP-dependent activation of type II protein kinase A [5]. In contrast, ATP stimulates $\mathrm{Cl}^{-}$secretion through $\mathrm{Ca}^{2+}$-activated $\mathrm{Cl}^{-}$channels. This signaling pathway involves $\mathrm{P}_{2} \mathrm{Y}_{2}$ receptors, leading to $\mathrm{G}$ protein-coupled phospholipase $\mathrm{C}$ activation and cytosolic $\mathrm{Ca}^{2+}$ mobilization. Water efflux is also stimulated by $\mathrm{P}_{2} \mathrm{Y}_{2}$ receptor-mediated inhibition of $\mathrm{Na}^{+}$absorption by ENAC using $\mathrm{Ca}^{2+}$-dependent signaling pathways [21]. Members of the P2X receptor family also support luminal $\mathrm{Cl}^{-}$/water efflux in human airway
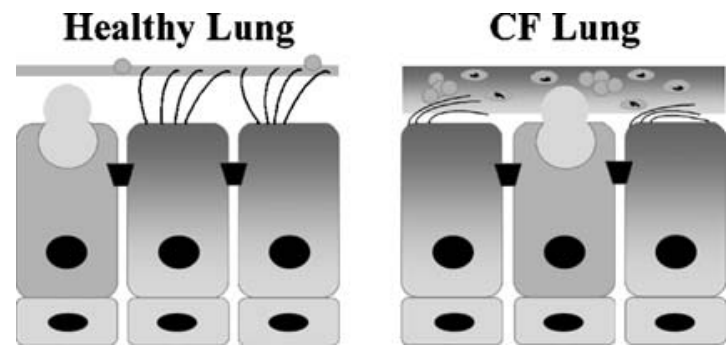

Fig. 1 Impact of chronic obstructive lung diseases on mucociliary clearance. The polarized epithelium is composed of columnar (ciliated or mucin-secreting) cells facing the lumen and basal cells facing the serosal compartment. Bacterial clearance in healthy lungs is maintained by coordinated cilia beating activity within the PCL layer, moving upward the overlying mucus and pathogens. In chronic obstructive lung diseases, cilia are collapsed under a thick layer of mucus containing bacteria and leukocytes. 
epithelia, as demonstrated in primary cultures and cell lines (Beas2B, 16HBE14o ${ }^{-}$, Calu-3, ( $\left(\mathrm{CFTE}-29 \mathrm{o}^{-}\right)$by Ussing chamber and patch-clamp experiments [22]. The receptors identified in airway epithelia by $\mathrm{RT}-$ $\mathrm{PCR}$ were $\mathrm{P} 2 \mathrm{X}_{2}, \mathrm{P} 2 \mathrm{X}_{4}$ and $\mathrm{P} 2 \mathrm{X}_{5}$. These non-selective cation channels allow $\mathrm{Ca}^{2+}$ influx, which then stimulates $\mathrm{Ca}^{2+}$-activated $\mathrm{Cl}^{-}$channels. Interestingly, $\mathrm{P}_{2} \mathrm{X}_{7}$ receptors are only detected in $\mathrm{CF}$ airway epithelia, primarily in nasal polyps [22]. Because they are known to induce apoptosis in response to high ATP concentrations [23], $\mathrm{P} 2 \mathrm{X}_{7}$ receptors may contribute to disease-associated epithelial damage.

The central role of ASL nucleotides for MCC was further substantiated by the observation that $\mathrm{P}_{2} \mathrm{Y}_{2}$ receptor activation constitutes the most potent stimulus for cilia beating activity [24-26] and mucin secretion [27, 28]. In cultured CF airway epithelia, $\mathrm{P}_{2} \mathrm{Y}_{2}$ receptor activation restores normal PCL height and rotational mucus transport [29]. Based on these findings, aerosolized nucleotides were proposed for the treatment of chronic obstructive lung diseases [16]. However, clinical studies showed that patients with asthma or chronic obstructive pulmonary disease exposed to aerosolized metabolites of ATP (AMP and adenosine) experience coughing and bronchoconstriction [30, 31]. Furthermore, aerosolized ATP (not adenosine) induced similar reactions from healthy subjects [32, 33]. In developing nucleotide-mediated MCC therapies, the equally potent $\mathrm{P}_{2} \mathrm{Y}_{2}$ receptor agonist, UTP, was evaluated [6]. Airway clearance in sheep, measured with nebulized technetium-labeled albumin, was transiently increased by UTP [34]. Aerosolized UTP also improved MCC in patients with mild chronic bronchitis [35], CF [36, 37] and primary ciliary dyskinesia [38].

A major obstacle to the treatment of chronic lung diseases with aerosolized UTP is the rapid disappearance of therapeutic concentrations $(0.1 \mathrm{mM})$ from the ASL layer $(<5 \mathrm{~min})[10,29]$. Incidentally, the metabolically stable UTP analogs INS365 (diquafosol) and INS37217 (denufosol) developed by Inspire Pharmaceuticals Inc. [39] were reported to improve cough induced-sputum clearance in $\mathrm{CF}$ patients [40, 41]. However, long-term treatments with these drugs may require dose optimization to minimize $\mathrm{P}_{2} \mathrm{Y}_{2}$ receptor desensitization [42].

\section{$P 2$ receptors and airway inflammation}

In vivo studies conducted on the injurious effects of mechanical ventilation demonstrated that endogenous
ATP may reach ASL concentrations sufficiently high to trigger inflammatory responses and lung damage in the absence of infection [43]. The bronchoalveolar lavage fluid of rats subjected to positive-pressure mechanical ventilation contains significantly higher protein, ATP and cytokine (IL-6, TNF $\alpha$ ) levels than control animals. Instillation of an equivalent ATP concentration increased lung fluid volume, supporting the existence of $\mathrm{P} 2$ and/or P1 receptor-mediated lung edema [43]. Analysis of bronchoalveolar lavage fluid nucleotide content by etheno-derivatization revealed an increase in AMP + adenosine/ADP + ATP ratio [44], suggesting that mechanical ventilation up-regulates airway ectonucleotidases. Real-time PCR on total lung tissue indicated that mechanical ventilation increases $\mathrm{A}_{2 \mathrm{~B}}$, but decreases $\mathrm{P} 2 \mathrm{X}_{7}$, receptor expression. Rats subjected to both mechanical ventilation and positive end-expiratory pressure exhibited normal bronchoalveolar lavage composition and receptor expression. These findings suggest that patients subjected to positive end-expiratory pressure during large-volume ventilation may avoid ATP-mediated lung injuries. On the other hand, the fact that adenosine levels and $\mathrm{A}_{2 \mathrm{~B}}$ receptor expression were raised, whereas ATP levels and $\mathrm{P} 2 \mathrm{X}_{7}$ receptor expression were decreased, by mechanical ventilation supports a dynamic role for ectonucleotidases in the regulation of purine signaling in the airways.

The role of $\mathrm{P} 2$ receptors in innate defense against bacterial infection was investigated using mice deficient in $\mathrm{P}_{2} \mathrm{Y}_{1}, \mathrm{P}_{2} \mathrm{Y}_{2}$ or both receptors [45]. All these mice exhibited lower survival and lower cytokine levels in lung homogenates than wild-type animals measured $24 \mathrm{~h}$ after intranasal instillation of $P$. aeruginosa. These results suggest a protective role for ATP-induced inflammation [45]. In human airways, $\mathrm{P}_{2} \mathrm{Y}_{2}$ receptor activation amplified inflammatory responses to bacterial infection. Primary cultures of bronchial epithelial cells exposed to UTP and sputum from CF patients exhibited an eight-fold increase in IL-8 secretion, compared to two-fold with UTP alone [46]. Furthermore, $\mathrm{P}_{2} \mathrm{X}_{7}$ receptors are known to support several processes relevant to inflammation, including LPS neutralization [47], pathogen killing, nitric oxide production [1] and cytokine release from mast cells, leukocytes, dendritic cells and neurons [3, 14]. In human blood, LPS-induced IL- $1 \beta$ release is increased 5-fold by $\mathrm{P} 2 \mathrm{X}_{7}$ receptor activation [48]. Altogether, these studies entail that P2 receptor activation may not only induce innate immunity but also amplify pathogen-induced inflammatory responses in chronic infectious lung diseases. 


\section{Too much of a good thing..}

Excessive inflammatory response to recurrent bacterial infection is a major component in the pathogenesis of chronic lung diseases, irreversibly damaging the airways and leading to bronchiectasis and respiratory failure [49-51]. With respect to purine signaling, nucleotide-mediated cell communications may be overwhelmed by massive ATP release from cell lysis of bacteria and damaged epithelia, as well as stimulated leukocytes and epithelia [6]. The sensitivity of certain $\mathrm{P} 2$ receptors $\left(\mathrm{P}_{2} \mathrm{Y}_{2}\right.$ [42], $\mathrm{P} 2 \mathrm{X}_{1}$ and $\mathrm{P} 2 \mathrm{X}_{3}$ [52]) to agonist-induced desensitization may reduce the efficiency of nucleotide-mediated MCC [53]. On the other hand, chronically elevated ATP may recruit signaling pathways normally dormant in healthy lungs. For instance, $\mathrm{P} 2 \mathrm{X}_{7}$ receptor activation only induces cytokine release and cell death in response to high ATP concentrations encountered in damaged tissues [23]. On astrocytes, LPS-induced $\mathrm{TNF} \alpha$ secretion is increased by $\mathrm{P} 2 \mathrm{Y}$ receptor activation at low micromolar ATP, but reduced by $\mathrm{P}_{2} \mathrm{X}_{7}$ receptor activation at high ATP concentrations [54]. The authors propose a beneficial effect for the potentiation of TNF $\alpha$ secretion by $\mathrm{P} 2 \mathrm{Y}$ receptors during mild or acute inflammation and a protective role for $\mathrm{P}_{2} \mathrm{X}_{7}$ receptors in damaged tissues or chronic infectious diseases. These studies suggest that $\mathrm{P} 2 \mathrm{X}_{7}$ receptor-mediated responses may be tissue-specific and/or influenced by bacterial infections. In the respiratory system, $\mathrm{P}_{2} \mathrm{Y}_{2}$ receptors are expressed throughout airway epithelia [39] while $\mathrm{P}_{2} \mathrm{X}_{7}$ receptors have only been reported in nasal polyps of $\mathrm{CF}$ patients [22]. The impact of $\mathrm{P} 2 \mathrm{X}$ and $\mathrm{P} 2 \mathrm{Y}$ receptor activation on inflammatory responses mediated by airway epithelia under normal and pathological conditions remains to be investigated.

\section{E-NTPDases regulate airway ATP}

Several studies demonstrate the presence of ectonucleotidase activities on human airway epithelia $[9,10$, 55-58]. Time-course experiments conducted on polarized primary cultures of human bronchial epithelial cells showed that mucosal ATP is dephosphorylated into ADP, AMP and adenosine (Fig. 2a). Experiments repeated with nasal, bronchial and bronchiolar epithelial cultures indicated that ATP metabolism accelerates toward the alveolar region (Fig. 2b). Such gradient distribution was also reported for non-specific alkaline phosphatase (NS AP) in human airways [9], an ectonucleotidase capable of sequentially dephos- phorylating ATP to adenosine [59]. However, complete inhibition of NS AP with $10 \mathrm{mM}$ levamisole [9] only reduced by $25 \%$ total ectoATPase activities [10]. Other ATP-regulating ectonucleotidases were identified in mammalian tissues as members of the ENTPDase family $[15,60]$. They catalyze the hydrolysis of $\gamma$ - and/or $\beta$-phosphate residues, resulting in the formation of nucleoside monophosphates. Their activities are $\mathrm{Ca}^{2+}$ and $\mathrm{Mg}^{2+}$-dependent and insensitive to inhibitors of P-, F- and V-type ATPases or APs [61]. Four E-NTPDases are localized to cell surfaces: NTPDase 1, 2, 3 and 8. Functional studies showed that NTPDase 1 [62] and NTPDase 3 [63] are inhibited by azide, whereas NTPDase 2 [64] and NTPDase 8 [65] are insensitive. The mRNA expression of NTPDase 1, 2 and 3 in human airways was reported in total lung RNA [66] and cultured bronchial epithelial cells [67]. We now provide evidence that NTPDase 1 and NTPDase 3 are both expressed throughout human airways by real-time PCR on freshly excised epithelial cells (Fig. 3). Their expression distribution followed surface ectoATPase activities (Fig. 2b), exhibiting higher mRNA levels in smaller airways (Fig. 3). The fact that $20 \mathrm{mM}$ azide reduced total ectoATPase activities by $45 \%$ on human bronchial epithelial cells [67] suggests that the high affinity $\left(\mathrm{K}_{\mathrm{m}}<15 \mu \mathrm{M}\right)$ [68] NTPDases 1 and/or 3 play major roles in the regulation of physiological ASL nucleotide concentrations.

The physiological importance of azide-sensitive ENTPDases for nucleotide-mediated MCC was recently established using an in vitro model of rhythmic
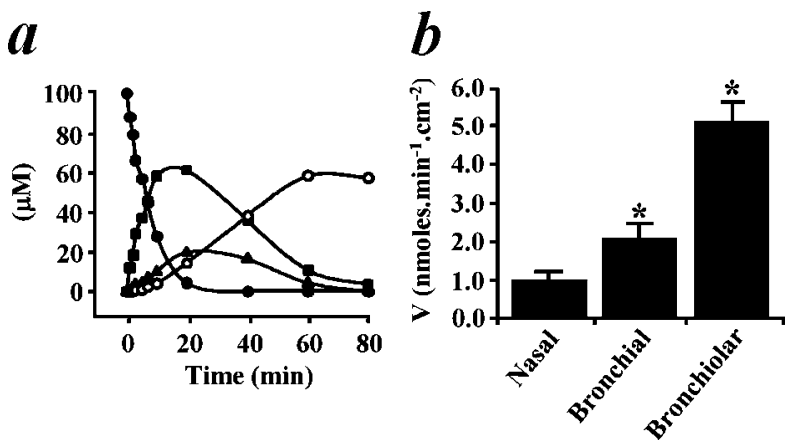

Fig. 2 Ectonucleotidases regulate nucleotide concentrations on airway epithelial surfaces. a Polarized primary cultures of human bronchial epithelial cells were assayed with $100 \mu \mathrm{M}$ ATP added to the mucosal surface, as we previously described [10]. Buffer sample analysis by high-pressure liquid chromatography (10) shows that exogenous ATP $(\bullet)$ is dephosphorylated into ADP (घ), AMP ( $\mathbf{\Delta})$ and adenosine (O). b Similar experiments repeated on primary cultures of human nasal, bronchial and bronchiolar epithelial cells show that the elimination rate of ATP increases toward alveoli $(N=3, *, P<0.05$; Mann-Whitney test). 


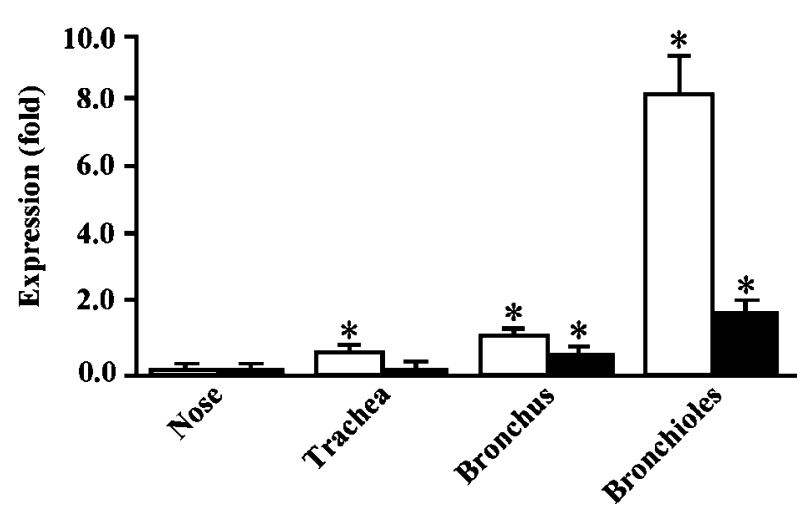

Fig. 3 Expression level of NTPDase 1 and NTPDase 3 along human airways. Total RNA from excised epithelia was analyzed by real-time PCR using SYBR green assays and normalized to the expression level of the house-keeping gene, 18S, as we previously described [89]. The mRNA level of E-NTPDase 1 ( $\square$ ) and NTPDase $3(\square)$ increases toward alveoli $(N=4, *, P<0.05$; Mann-Whitney test).

breathing. Airway epithelia are continuously subjected to mechanical stress generated by breathing, coughing or chest movement. Since mechanical stress induces epithelial ATP release [6], static culture conditions may underestimate the lungs capacity to regulate MCC in vivo. Rhythmic pressure changes mimicking normal tidal breathing were reproduced in vitro by a system applying cyclic compressive stress (CCS) to the mucosal surface of primary bronchial epithelial cultures [69]. Whereas CF cultures under static conditions exhibit a depleted PCL layer and mucostasis, CCS mimicking normal tidal breathing $\left(20 \mathrm{cmH}_{2} \mathrm{O} ; 15\right.$ cycles/min) restored normal PCL height and mucus transport through ATP release and $\mathrm{P}_{2} \mathrm{Y}_{2}$ receptor activation. These results also suggest that purine signaling may provide an explanation for the beneficial effects of oscillatory therapeutic devices clinically used to stimulate sputum clearance [70].

Cyclic compressive stress also enhances MCC through a reduction in ASL nucleotide metabolism. We recently demonstrated that CCS decreases the rate of ATP hydrolysis on the mucosal surface of normal and CF bronchial epithelial cultures [67]. More importantly, CCS restored normal ectoATPase activities on CF epithelial surfaces. The inhibitory effect of CCS on ATP metabolism was abrogated by $20 \mathrm{mM}$ azide, indicating that E-NTPDase 1 and/or E-NTPDase 3 are key components in the regulation $\mathrm{P} 2$ receptormediated MCC. Perhaps the ability of CF airway epithelia to provide adequate nucleotide-mediated MCC under conditions mimicking normal breathing may contribute to the relatively healthy state of young patients before the establishment of chronic infection [71].

\section{Chronic lung diseases shorten the signals}

Recent studies demonstrate that chronic lung diseases accelerate all metabolic steps supporting the mucosal conversion of ATP to adenosine [10, 72]. We identified the ectonucleotidases involved using primary bronchial epithelial cultures from healthy donors and patients with primary ciliary dyskinesia, CF or $\alpha 1$-antitrypsin deficiency. All airway diseases were characterized by a two- to four-fold increase in the elimination rate of ATP on the mucosal surface, without significant effect on the serosal surface (Fig. 4). Selective inhibitors of NS AP (10 mM levamisole), NTPDase 1 and NTPDase 3 (20 $\mathrm{mM}$ azide) partially restored normal activity levels. However, the lower substrate affinities of airway NS AP $(36 \mu \mathrm{M}$ and $717 \mu \mathrm{M})$ [9] suggest that NTPDase 1 and/or NTPDase 3 are responsible for the accelerated clearance of $\mathrm{P} 2$ receptor agonists in diseased airways.

Pseudomonas aeruginosa is among the most frequently isolated pathogens from the airways of patients with gram-negative infections [51]. In patients with damaged airways from mechanical ventilation, trauma or viral infection, airway colonization by $P$. aeruginosa is often followed by pneumonia, sepsis and death. Much of the airway inflammation induced by these organisms is caused by released bacterial products adhering to the epithelial surface, such as LPS. The contribution of bacterial infection to the deregulation of E-NTPDase activities in lung diseases was

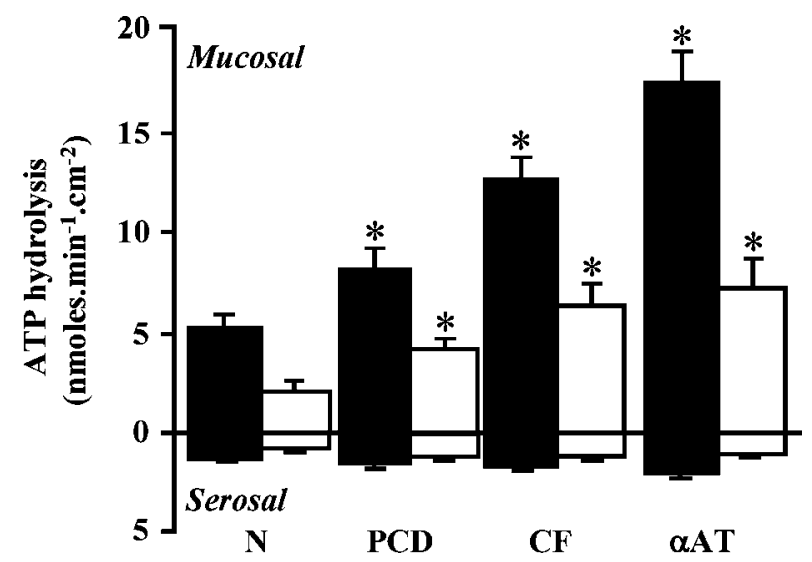

Fig. 4 Chronic lung diseases enhance azide-sensitive ENTPDases. Primary bronchial epithelial cultures from healthy donors $(N)$ and patients diagnosed with primary ciliary dyskinesia (PCD), CF or $\alpha 1$-antitrypsin deficiency $(\alpha$ AT) were assayed with bilateral $1 \mathrm{mM}$ ATP in the absence $(\square)$ or presence $(\square)$ of $20 \mathrm{mM}$ azide, as we previously described [10]. Analysis of buffer samples by high-pressure liquid chromatography showed that azide-sensitive E-NTPDases are concentrated on the mucosal surface under normal and pathological conditions $(N=4, *, P<$ 0.05; Mann-Whitney test). 
examined using $P$. aeruginosa LPS. Primary cultures of human bronchial epithelial cells exposed $24 \mathrm{~h}$ on the mucosal surface to an optimum LPS concentration (100 ng/ml) [73] exhibited a biphasic response over time (Fig. 5A). Azide-sensitive E-NTPDases were transiently reduced over $8 \mathrm{~h}$, without affecting mRNA expression. In contrast, prolonged exposures $(24 \mathrm{~h})$ raised the activities two-fold above control levels and increased NTPDase 1 and NTPDase 3 expression by 4 and 10-fold (Fig. 5B). These opposite effects suggest that two regulatory mechanisms may be involved in the acute and chronic effects of LPS on airway ENTPDases.

Oxidative stress is one of the major causes of epithelial injury in chronic lung diseases [74]. Reactive oxygen and nitrogen species released from airway epithelia or activated leukocytes damage cell membranes by peroxidation of lipids, amino acids and carbohydrates. $P$ aeruginosa LPS was reported to induce their release from airway epithelia [75]. Incidentally, intrahepatic cholestasis induced by intraperitoneal injection of LPS reduced total liver NTPDase 1 activity within $2 \mathrm{~h}$ [76]. In a rat model of glomerulopathy, short-term exposure $(1 \mathrm{~h})$ to LPS inactivated endothelial NTPDase 1, which was prevented by pre-treatment with the anti-oxidant superoxide dismutase [77]. Oxidative stress induced by membrane depolarization [78] or ischemia/ reperfusion [79] also inhibited endothelial NTPDase 1. Furthermore, short exposures $(4 \mathrm{~h})$ to the pro-inflammatory cytokine, $\mathrm{TNF} \alpha$, inhibited endothelial NTPDase 1, which was mimicked by hydrogen peroxide but prevented by superoxide dismutase [80]. Altogether, these studies suggest that oxidative stress may be responsible for the early and transient reduc-

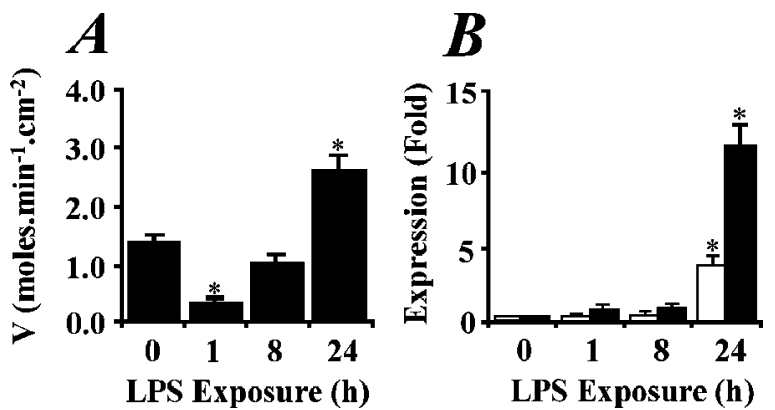

Fig. 5 Impact of $P$. aeruginisa LPS on NTPDase 1 and NTPDase 3. A The mucosal surface of primary bronchial epithelial cultures were exposed $0,1,8$ or $24 \mathrm{~h}$ to $100 \mathrm{ng} / \mathrm{ml} \mathrm{LPS}$, then assayed for surface activity by high-pressure liquid chromatography, as we previously described [10]. The activities of azidesensitive mucosal E-NTPDases measured with $0.03 \mathrm{mM}$ ATP were transiently reduced by LPS. B Quantification of their mRNA expression by real-time PCR using the house-keeping gene $18 \mathrm{~S}$, as we previously described (89). LPS induced a delayed increase in the expression level of both E-NTPDases $(N=5, *, P<0.05$; Mann-Whitney test $)$. tion in azide-sensitive E-NTPDase activities detected in LPS-treated airway epithelia. Since the mRNA expression of E-NTPDases is unaffected by acute oxidative stress [80] or LPS (Fig. 5B), and the inactivation of NTPDase 1 by ischemia/reperfusion was prevented by inhibitors of lipid peroxidation [79], the early loss of surface activity may involve local peroxidation of membrane lipids.

The long-term effects of LPS on the azide-sensitive E-NTPDases have not been documented in mammalian tissues. On the other hand, a $24 \mathrm{~h}$ exposure to endotoxin stimulated NTPDase 2 on astrocytes [81], as well as NS AP on endothelial, mesengial [82, 83] and bronchial epithelial [73] cells. Additionally, the mRNA expression of NTPDase 1 in rat forebrain was upregulated seven days after transient ischemia [84]. $P$. aeruginosa LPS [85, 86] is well-known to influence gene expression through the activation of the transcription factors: Nuclear factor-kappa B and activator protein-1 [87]. Recent studies have shown that CFTR acts as a pattern recognition molecule for $P$. aeruginosa LPS [88]. Endocytosis of the complex triggers translocation of these transcription factors to the nucleus, which initiates innate immunity through the expression of numerous mediators recruiting and activating inflammatory cells. These signaling pathways could be involved in the up-regulation of NTPDase 1 and NTPDase 3 expression resulting from long-term exposures to $P$. aeruginosa LPS in human airways.

\section{Adaptation of purine signaling to airway diseases}

In past decade, the therapeutic potential of aerosolized nucleotides for the treatment of chronic obstructive lung diseases has motivated numerous studies on the importance of purine signaling in the airways. This elaborated cell communication system is involved in major defense mechanisms including bacterial clearance and inflammatory responses to bacterial infection. Each signaling event constitutes a brief 'on-and-off' switch mechanism allowing the target cells to perceive the subsequent signal. Environmental changes are communicated to target cells in the form of released ATP, which binds surface receptors and triggers an appropriate response. The efficiency of this communication system depends on the cells capacity to rapidly eliminate these local bursts in extracellular ATP concentrations to prevent receptor desensitization. This review establishes the pivotal role of E-NTPDases in the regulation of airway defenses mediated by purine signaling, namely bacterial clearance (Fig. 6). Cyclic 


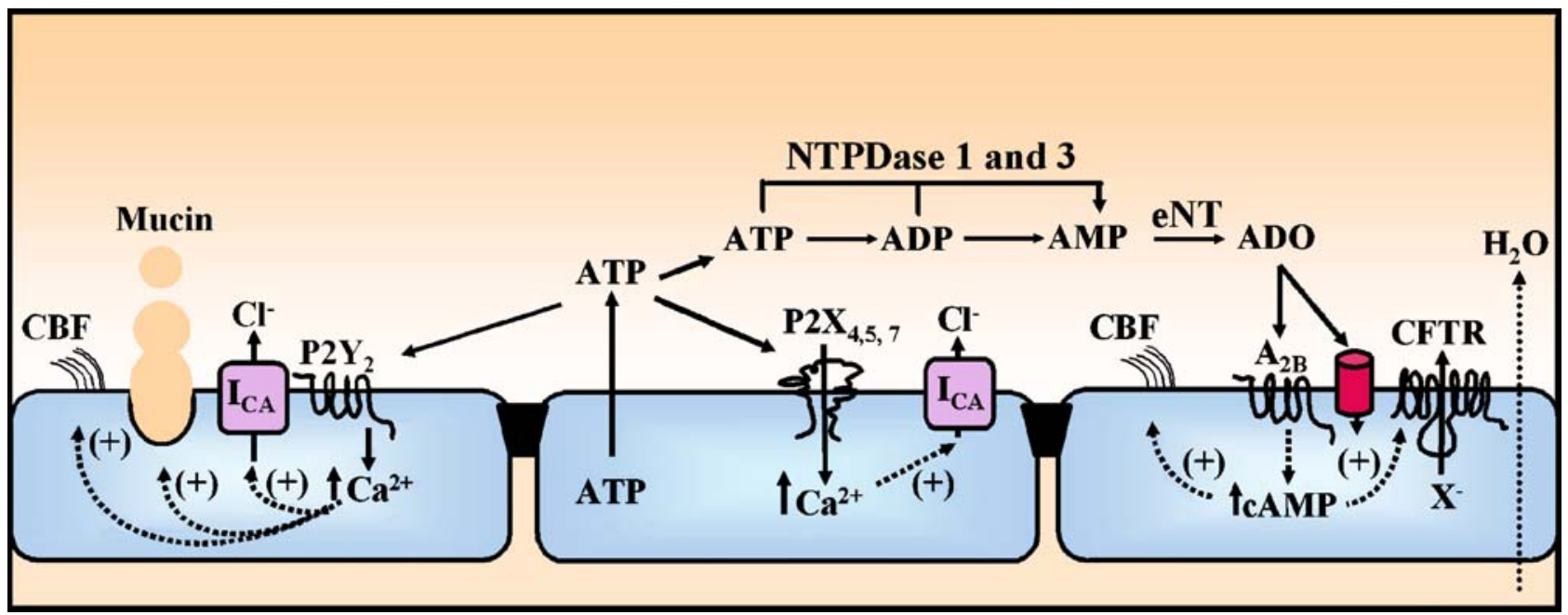

Fig. 6 Purine signaling and nucleotide salvage pathways on human airway epithelia. In normal lungs, basal adenosine levels maintain adequate PCL height for mucus transport through $\mathrm{A}_{2 \mathrm{~B}}$ receptor-mediated CFTR activity. Mechanical stimulation of the epithelial surface by an irritant, a pathogen, mechanical ventilation or cyclic compressive stress induces ATP release and elevates ASL concentrations above activation threshold level for $\mathrm{P}_{2} \mathrm{Y}_{2}$ receptor activation. This autocrine signal transiently enhances basal MCC through cilia beating, mucin secretion and ion/water efflux into the lumen. The signal is rapidly terminated by NTPDase 1 and/or NTPDase 3 dephosphorylating excess ATP to AMP. Ecto 5'-nucleotidase (ecto $5^{\prime}$-NT; CD73) produces ASL adenosine from the resulting AMP, and excess adenosine is transported back to the cytosol. Chronic lung diseases burdened by considerable tissue damage recruits additional receptors $\left(\mathrm{P} 2 \mathrm{X}_{4,5}, 7\right)$ responding to higher ATP cocnentrations.

compressive stress, mimicking normal breathing or clinical oscillatory devices, stimulates $\mathrm{P} 2$ receptormediated MCC through ATP release and reduced azide-sensitive E-NTPDase activities. We also presented original data indicating that NTPDase 1 and 3 activities and expressions are up-regulated in chronic lung diseases by inflammatory mediators, including endotoxin. Interestingly, $P$. aeruginosa LPS generated a biphasic modulation of airway E-NTPDases which may reconcile previous conflicting reports based on exposure duration. Acute LPS exposures reduced ENTPDase activities, as observed during CCS, most likely to clear a pathogen through $\mathrm{P} 2$ receptor-mediated MCC. The signaling pathways activated by $P$. aeruginosa LPS and the lack of concomitant reduction in ENTPDase mRNA levels support a local inhibitory mechanism that may involve oxidative stress-mediated membrane damage. On the other hand, prolonged endotoxin exposures mimicked the impact of chronic lung diseases on NTPDases 1 and 3, characterized by an up-regulation of both activities and mRNA expression. In chronically infected lungs, an increase in ENTPDase activities may represent an attempt to prevent lung damage, excessive inflammation and P2 receptor desensitization by chronically elevated ATP concentrations.

The information provided in this review also exposes the complexity of the signaling interactions taking place between different classes of mediators, including bacterial products, cytokines and extracellu- lar nucleotides, as combinations of mediators may induce different responses than when tested individually. Furthermore, communication networks in the airways may evolve with time during the establishment of a chronic infection, as new target cells (bacteria, leukocytes, lymphocytes) agglomerate on either side of the epithelial barrier. It is proposed that nucleotidemediated airway functions defined in normal tissues or aseptic culture conditions may require reassessment under conditions mimicking chronic lung diseases before their therapeutic potential may be clearly established.

Acknowledgments The human nasal and bronchial epithelial cells were provided by the Tissue Culture Core of the Cystic Fibrosis Center (UNC-CH), directed by Dr Scott H. Randell. This work was supported by the Cystic Fibrosis Foundation (Picher 02I0 and Picher 05G0).

\section{References}

1. Pelleg A, Schulman E (2002) Adenosine 5'-triphosphate axis in obstructive airway diseases. Am J Ther 9:454-64

2. Burnstock G, Knight GE (2004) Cellular distribution and functions of P2 receptor subtypes in different systems. Int Rev Cytol 240:31-304

3. Dubyak GR (2000) Purinergic signaling at immunological synapses. J Auton Nerv Syst 81:64-8

4. Homolya L, Steinberg TH, Boucher RC (2000). Cell to cell communication in response to mechanical stress via bilateral release of ATP and UTP in polarized epithelia. J Cell Biol 150:1349-60 
5. Huang P, Lazarowski ER, Tarran R et al (2001) Compartmentalized autocrine signaling to cystic fibrosis transmembrane conductance regulator at the apical membrane of airway epithelial cells. Proc Natl Acad Sci USA 98:14120-5

6. Lazarowski ER, Boucher RC, Harden TK (2003) Mechanisms of release of nucleotides and integration of their action as P2X- and P2Y-receptor activating molecules. Mol Pharmacol 64:785-95

7. Gabriel SE (2002) Calcium-activated Cl-conductance in the airway epithelium. In: Fuller CM (ed) Current topics in membranes. San Diego, Elsevier Science, pp 193-207

8. Boeynaems JM, Communi D, Gonzalez NS et al (2005) Overview of the P2 receptors. Semin Thromb Hemost 31:139-49

9. Picher M, Burch LH, Hirsh AJ et al (2003) Ecto 5'nucleotidase and nonspecific alkaline phosphatase. Two AMP-hydrolyzing ectoenzymes with distinct roles in human airways. J Biol Chem 278:13468-79

10. Picher M, Burch LH, Boucher RC (2004) Metabolism of P2 receptor agonists in human airways: Implications for mucociliary clearance and cystic fibrosis. J Biol Chem 279: 20234-41

11. Fredholm BB (2003) Adenosine receptors as targets for drug development. Drug News Perspect 16:283-9

12. Boucher RC (2004) New concepts of the pathogenesis of cystic fibrosis lung disease. Eur Respir J 23:146-58

13. Greenberg S, Zhao X, Wang J et al (1997) cAMP and purinergic $\mathrm{P} 2 \mathrm{Y}$ receptors up-regulate and enhance inducible NO synthase mRNA and protein in vivo. Am J Physiol 273: L967-79

14. La Sala A, Ferrari D, Di Virgilio F et al (2003) Alerting and tuning the immune response by extracellular nucleotides. J Leukoc Biol 73:339-43

15. Zimmermann H (2001) Ectonucleotidases: Some recent developments and a note on nomenclature. Drug Dev Res 52:44-56

16. Boucher RC (2004) New concepts of the pathogenesis of cystic fibrosis lung disease. Eur Respir J 23:146-58

17. Tarran R, Boucher RC (2002) Thin-film measurements of airway surface liquid volume/composition and mucus transport rates in vitro. Methods Mol Med 70:479-92

18. Roomans GM, Kozlova I, Nilsson H et al (2004) Measurements of airway surface liquid height and mucus transport by fluorescence microscopy, and of ion composition by X-ray microanalysis. J Cyst Fibros 3(Suppl 2):135-9

19. Tarran R (2004) Regulation of airway surface liquid volume and mucus transport by active ion transport. Proc Am Thorac Soc 1:42-6

20. Gabriel SE, Boucher RC (1997) Ion channels. In: Crystal RG, West JB (eds) The lung. Philadelphia, LippincottRaven, pp 205-318

21. Mall M, Wissner A, Gonska T et al (2000) Inhibition of amiloride-sensitive epithelial $\mathrm{Na}^{+}$absorption by extracellular nucleotides in human normal and cystic fibrosis airways. Am J Respir Cell Mol Biol 23:755-61

22. Taylor AL, Schwiebert LM, Smith JJ et al (1999) Epithelial $\mathrm{P} 2 \mathrm{X}$ purinergic receptor channel expression and function. $\mathrm{J}$ Clin Invest 104:875-84

23. Adinolfi E, Pizzirani C, Idzko $\mathrm{M}$ et al (2005) $\mathrm{P} 2 \mathrm{X}_{7}$ receptor: Death or life? Purin Signal 1:219-27

24. Wong LB, Yeates DB (1992) Luminal purinergic regulatory mechanisms of tracheal ciliary beat frequency. Am J Respir Cell Mol Biol 7:447-54

25. Evans JH, Sanderson MJ (1999) Intracellular calcium oscillations regulate ciliary beat frequency of airway epithelial cells. Cell Calcium 26:103-10
26. Morse DM, Smullen JL, Davis CW (2001) Differential effects of UTP, ATP, and adenosine on ciliary activity of human nasal epithelial cells. Am J Physiol 280:C1485-97

27. Davis C (2002) Regulation of mucin secretion in in vitro cellular models. Novartis Found Symp 248:113-25

28. Conway JD, Bartolotta T, Abdullah LH, Davis CW (2003) Regulation of mucin secretion from human bronchial epithelial cells grown in murine hosted xenografts. Am J Physiol 284:L945-54

29. Tarran R, Grubb BR, Parsons D et al (2001) The CF salt controversy: In vivo observations and therapeutic approaches. Mol Cell 8:149-58

30. Polosa R, Rorke S, Holgate ST (2002) Evolving concepts on the value of adenosine hyperresponsiveness in asthma and chronic obstructive pulmonary disease. Thorax 57:649-54

31. Van den Berge M, Polosa R, Kerstjens HAM et al (2004) The role of endogenous and exogenous AMP in asthma and chronic obstructive pulmonary disease. J Allergy Clin Immunol 114:737-46

32. Basoglu OK, Pelleg A, Essilfie-Quaye S et al (2005) Effects of aerosolized adenosine $5^{\prime}$-triphosphate vs adenosine $5^{\prime}$ monophosphate on dyspnea and airway caliber in healthy nonsmokers and patients with asthma. Chest 128:1905-9

33. Pellegrino R, Wilson O, Jenouri G et al (1996) Lung mechanics during induced bronchoconstriction. J Appl Physiol 81:964-75

34. Sabater JR, Mao YM, Shaffer C et al (1999) Aerosolization of $\mathrm{P}_{2} \mathrm{Y}_{2}$-receptor agonists enhances mucociliary clearance in sheep. J Appl Physiol 87:2191-6

35. Bennett WD, Zeman KL, Foy C et al (2001) Effect of aerosolized uridine $5^{\prime}$-triphosphate on mucociliary clearance in mild chronic bronchitis. Am J Respir Crit Care Med 164:302-6

36. Bennett WD, Olivier KN, Zeman KL et al (1996) Effect of uridine $5^{\prime}$-triphosphate plus amiloride on mucociliary clearance in adult cystic fibrosis. Am J Respir Crit Care Med 153:1796-801

37. Olivier KN, Bennett WD, Hohneker KW et al (1996) Acute safety and effects on mucociliary clearance of aerosolized uridine $5^{\prime}$-triphosphate $+/-$ amiloride in normal human adults. Am J Respir Crit Care Med 154:217-23

38. Noone PG, Bennett WD, Regnis JA et al (1999) Effect of aerosolized uridine- $5^{\prime}$-triphosphate on airway clearance with cough in patients with primary ciliary dyskinesia. Am J Respir Crit Care Med 160:144-9

39. Yerxa BR, Sabater JR, Davis CW et al (2002) Pharmacology of INS37217 [P1-(uridine 5')-P4- (2'-deoxycytidine 5') tetraphosphate, tetrasodium salt], a next-generation $\mathrm{P}_{2} \mathrm{Y}_{2}$ receptor agonist for the treatment of cystic fibrosis. J Pharmacol Exp Ther 302:871-80

40. Kellerman D, Evans R, Mathews D, Shaffer C (2002) Inhaled $\mathrm{P}_{2} \mathrm{Y}_{2}$ receptor agonists as a treatment for patients with Cystic Fibrosis lung disease. Adv Drug Deliv Rev 54: 1463-74

41. Deterding R, Retsch-Bogart G, Milgram L et al (2005) Safety and tolerability of denufosol tetrasodium inhalation solution, a novel $\mathrm{P} 2 \mathrm{Y}_{2}$ receptor agonist: Results of a phase 1/ phase 2 multicenter study in mild to moderate cystic fibrosis. Pediatr Pulmonol 39:339-48

42. Clarke LL, Harline MC, Otero MA et al (1999) Desensitization of $\mathrm{P}_{2} \mathrm{Y}_{2}$ receptor-activated transepithelial anion secretion. Am J Physiol Cell Physiol 276:C777-87

43. Rich PB, Douillet CD, Mahler SA et al (2003) Adenosine triphosphate is released during injurious mechanical ventilation and contributes to lung edema. J Trauma 55:290-7 
44. Douillet CD, Robinson WP III, Zarzaur BL et al (2005) Mechanical ventilation alters airway nucleotides and purinoceptors in lung and extrapulmonary organs. Am J Respir Cell Mol Biol 32:52-8

45. Geary C, Akinbi HT, Korfhagen T et al (2005) Increased susceptibility of purinergic receptor deficient mice to lung infection with Pseudomonas aeruginosa. Am J Physiol 289:L890-5

46. Ribeiro CMP, Paradiso AM, Schwab U et al (2005) Chronic airway infection/inflammation induces a $\mathrm{Ca}^{2+}$ independent hyperinflammatory response in human cystic fibrosis airway epithelia. J Biol Chem 280:17798-806

47. Denlinger LC, Fisette PL, Sommer JA et al (2001) Cutting Edge: The nucleotide receptor $\mathrm{P}_{2} \mathrm{X}_{7}$ contains multiple protein- and lipid-interaction motifs including a potential binding site for bacterial lipopolysaccharide. J Immunol 167:1871-6

48. Perregaux DG, McNiff P, Laliberte R et al (2000) ATP Acts as an agonist to promote stimulus-induced secretion of IL- $1 \beta$ and IL-18 in human blood. J Immunol 165:4615-23

49. Brown EA, Hoffmann SP (2002) Update in pulmonary medicine. Clin Pediatr Med Surg 19:1-22

50. Boucher RC (2004) Relationship of airway epithelial ion transport to chronic bronchitis. Proc Am Thorac Soc 1:66-70.

51. Sadikot RT, Blackwell TS, Christman JW, Prince AS (2005) Pathogen-host interactions in Pseudomonas aeruginosa pneumonia. Am J Respir Crit Care Med 171:1209-23

52. North RA, Surprenant A (2000) Pharmacology of cloned P2X receptors. Ann Rev Pharmacol Toxicol 40:563-80

53. Otero M, Garrad R, Velazquez B et al (2000) Mechanisms of agonist-dependent and -independent desensitization of a recombinant $\mathrm{P}_{2} \mathrm{Y}_{2}$ nucleotide receptor. Mol Cell Biochem 205:115-23

54. Kucher BM, Neary JT (2005) Bi-functional effects of ATP/ $\mathrm{P} 2$ receptor activation on tumor necrosis factor-alpha release in lipopolysaccharide-stimulated astrocytes. J Neurochem 92:525-35

55. Picher M, Boucher RC (2000) Biochemical evidence for an ecto alkaline phosphodiesterase I in human airways. Am J Respir Cell Mol Biol 23:255-61

56. Donaldson SH, Lazarowski ER, Picher M et al (2000) Basal nucleotide levels, release, and metabolism in normal and cystic fibrosis airways. Mol Med 6:969-82

57. Lazarowski ER, Boucher RC, Harden TK (2000) Constitutive release of ATP and evidence for major contribution of ecto-nucleotide pyrophosphatase and nucleoside diphosphokinase to extracellular nucleotide concentrations. J Biol Chem 275:31061-8

58. Donaldson SH, Picher M, Boucher RC (2000) Secreted and cell-associated adenylate kinase and nucleoside diphosphokinase contribute to extracellular nucleotide metabolism on human airway surfaces. Am J Respir Cell Mol Biol 26:209-15

59. Fortuna R, Anderson HC, Carty RP, Sajdeja SW (1980) Enzymatic characterization of the matrix vesicle alkaline phosphatase isolated from bovine epiphyseal cartilage. Calcif Tissue Int 30:217-25

60. Zimmermann H (2000) Extracellular metabolism of ATP and other nucleotides. Naunyn-Schmiedeberg's Arch Pharmacol 362:299-309

61. Plesner L (1995) Ecto-ATPases: Identities and functions. Int Rev Cytol 158:141-214

62. Leal DBR, Streher CA, Neu TN et al (2005) Characterization of NTPDase (NTPDase 1; ecto-apyrase; ecto-diphosphohydrolase; CD39; EC 3.6.1.5) activity in human lymphocytes. Biochim Biophys Acta 1721:9-15
63. Smith TM, Kirley TL (1998) Cloning, sequencing and expression of a human brain ecto-apyrase related to both the ecto-ATPase and CD39 ecto-apyrase 1. Biochim Biophys Acta 1386:65-78

64. Shi XJ, Knowles AF (1994) Prevalence of the mercurialsensitive ectoATPase in human small cell lung carcinoma: Characterization and partial purification. Arch Biochem Biophys 315:177-84

65. Sevigny J, Robson SC, Waelkens E et al (2000) Identification and characterization of a novel hepatic canalicular ATP diphosphohydrolase. J Biol Chem 275:5640-7

66. Chadwick BP, Frischauf AM (1998). The CD39-like gene family: Identification of three new human members (CD39L2, CD39L3, and CD39L4), their murine homologues, and a member of the gene family from Drosophila melanogaster. Genomics 50:357-67

67. Picher M, Button B, Boucher R (2005) Therapeutic potential of ebselen for nucleotide-mediated mucociliary clearance in the lungs of cystic fibrosis patients. Pediatr Pulmonol 28:274.

68. Kukulski F, Levesque SA, Lavoie EG et al (2005) Comparative hydrolysis of $\mathrm{P} 2$ receptor agonists by NTPDase 1, 2, 3 and 8. Purin Signal 1:193-204

69. Button B, Picher M, Lazarowski E, Boucher RC (2004) Sustained release and accumulation of nucleotides during cyclic compressive stress increases mucus clearance in CF human airway epithelial surfaces. Pediatr Pulmonol 27:213

70. App EM, Kieselmann R, Reinhardt D et al (1998) Sputum rheology changes in cystic fibrosis lung disease following two different types of physiotherapy: Flutter $v s$ autogenic drainage. Chest 114:171-7

71. Rosenfeld M, Ramsey B, Gibson R (2003) Pseudomonas acquisition in young patients with cystic fibrosis: Pathophysiology, diagnosis and management. Curr Opin Pulm Med 9:492-7

72. Picher M, Burch LH, Boucher RC (2000) Expression of alkaline phosphatase and ecto $5^{\prime}$-nucleotidase (CD73) in normal and CF airway epithelia. Pediatr Pulmonol 21:227

73. Picher M, Boucher RC (2003) Detoxification of Pseudomonas aeruginosa lipopolysaccharide in human airways: An inflammatory response mediated by non-specific alkaline phosphatase. Pediatr Pulmonol Suppl. 25:271

74. MacNee W (2005) Pulmonary and systemic oxidant/antioxidant imbalance in chronic obstructive pulmonary disease. Proc Am Thorac Soc 2:50-60

75. Rochelle LG, Fischer BM, Adler KB (1998) Concurrent production of reactive oxygen and nitrogen species by airway epithelial cells in vitro. Free Radic Biol Med 24:863-8

76. Zinchuk VS, Okada T, Seguchi H (2001) Lipopolysaccharide alters ecto-ATP-diphosphohydrolase and causes relocation of its reaction product in experimental intrahepatic cholestasis. Cell Tissue Res 304:103-9

77. Faas M, Schuiling G, Valkhof N et al (1998) Superoxidemediated glomerulopathy in the endotoxin-treated pregnant rat. Kidney Blood Press Res 21:432-7

78. Krotz F, Sohn HY, Keller M et al (2002) Depolarization of endothelial cells enhances platelet aggregation through oxidative inactivation of endothelial NTPDase. Arterioscler Thromb Vasc Biol 22:2003-9

79. Candinas D, Koyamada N, Miyatake T et al (1996) Loss of rat glomerular ATP diphosphohydrolase activity during reperfusion injury is associated with oxidative stress reactions. Thromb Haemost 76:807-12

80. Robson SC, Kaczmarek E, Siegel JB et al (1997) Loss of ATP diphosphohydrolase activity with endothelial cell activation. J Exp Med 185:153-64 
81. Kalmar B, Kittel A, Lemmens R et al (2001) Cultured astrocytes react to LPS with increased cyclooxygenase activity and phagocytosis. Neurochem Int 38:453-61

82. Kapojos JJ, Poelstra K, Borghuis T et al (2003) Induction of glomerular alkaline phosphatase after challenge with lipopolysaccharide. Int J Exp Pathol 84:135-44

83. Okada T, Zinchuk VS, Seguchi H (2002) Lipopolysaccharide administration increases acid and alkaline phosphatase reactivity in the cardiac muscle. Microsc Res Tech 58:421-6

84. Braun N, Zhu Y, Krieglstein J et al (1998) Up-regulation of the enzyme chain hydrolyzing extracellular ATP after transient forebrain ischemia in the rat. J Neurosci 18:4891-900

85. Pier GB, Grout M, Zaidi TS (1997) Cystic fibrosis transmembrane conductance regulator is an epithelial cell receptor for clearance of Pseudomonas aeruginosa from the lung. Proc Natl Acad Sci 94:12088-93
86. Schroeder TH, Lee MM, Yacono PW et al (2002) CFTR is a pattern recognition molecule that extracts Pseudomonas aeruginosa LPS from the outer membrane into epithelial cells and activates NF-kappa B translocation. Proc Natl Acad Sci 99:6907-12

87. Kikuchi T, Hagiwara K, Honda Y et al (2002) Clarithromycin suppresses lipopolysaccharide-induced interleukin-8 production by human monocytes through AP-1 and NF\{kappa\}B transcription factors. J Antimicrob Chemother 49:745-55

88. Pier GB (2002) CFTR mutations and host susceptibility to Pseudomonas aeruginosa lung infection. Curr Opin Microbiol 5:81-6

89. Voynow JA, Fischer BM, Malarkey DE et al (2004) Neutrophil elastase induces mucus cell metaplasia in mouse lung. Am J Physiol 287:L1293-302 